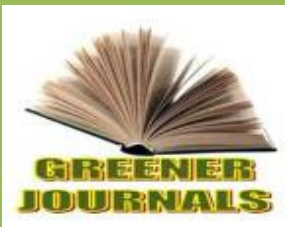

\title{
Impact of PRISM Approach on Area, Production and Income of Vegetable Growers in Kaski and Kapilvastu District of Western Nepal
}

\section{Bhimsen Gurung ${ }^{1}$, Punya Prasad Regmi ${ }^{2}$, Resham Bahadur Thapa ${ }^{2}$, Durga Mani Gautam², Ganesh Man Gurung $^{3}$ and Krishna Bahadur Karki ${ }^{4}$}

\author{
${ }^{1}$ Ph.D. Candidate in Agricultural Economic, IAAS, TU. \\ ${ }^{2}$ Professors, IAAS, TU. \\ ${ }^{3}$ Professor, Central Department of Sociology, TU. \\ ${ }^{4}$ Retired Chief Soil Scientist, NARC, Khumaltar.
}

Article No.: 110716200

DOI: 10.15580/GJAS.2016.10.110716200

Submitted: 07/11/2016

Accepted: 14/11/2016

Published: 30/11/2016

${ }^{\star}$ Corresponding Author

Bhimsen Gurung

E-mail: bhimseng@yahoo.com

Keywords:

PRISM, commercial vegetable

farming, Input supply, vegetable production and vegetable produce marketing
This study examines the impact of Prosperity Realization through Irrigation and Smallholder Market (PRISM) approach on increase of area under vegetable cultivation, production increase of vegetables and income increase of farmer in Kaski and Kapilvastu districts of Nepal. The project mainly intervened in networking of agricultural supplies to facilitate the small farmers to enhance production and productivity and marketing. After the project intervention, number of input suppliers increased with their services availability in time showing a positive impact in the area of input supply after the project. The technical capacity of the farmers was improved, farmers were organized in groups and the forward and backward linkages with input suppliers and output traders strengthen. The study indicated that the vegetable growers were able to sell their farm produce. In Kaski, the farmers almost doubled their income, i.e. from NRs. 33467 before the project to NRs. 60846 after the project. The farmers in Kapilvastu received $>10$ times increase in their farm income (NRs. 41259) after the project. After the project, non-farm income also significantly increased. The mean area of vegetable cultivation highly significantly increased after the project in Kaski and Kapilvastu as compared to before the project intervention. The study showed that the vegetable farming area and labor use highly significantly increased after the project in both, Kaski and Kapilvastu districts as compared to before the project intervention. Similarly, male female farm working and hired labor including their wages were found significant increased after the project. There was highly significant increase in production, consumption, and sale, gross and net income of vegetables farming in surveyed area over the period of ten years. The study revealed that the PRISM project has brought highly significant impact on the income of the farmers while comparing before and after the project intervention. The multiple regressed F-value pooled of both districts was highly significant explaining nearly $2 / 3$ rd of the vegetable production contributed by the seasonal vegetable growing farm plus hired labors $\left(R^{2}=64.55\right)$ working on the farm. This study concludes that the Government of Nepal needs to develop a policy to implement PRISM approach as a Program Planning tools for sustainable development. 


\section{INTRODUCTION}

The International Development Enterprises abbreviated as IDE is an INGO that has developed a market-oriented intervention designing approach called PRISM (Prosperity Realization through Irrigation and Smallholder Markets). It creates sustainable opportunities through market-oriented interventions, i.e. creating networks of small enterprises to provide agricultural supplies needed by poor farmers; working with farmers to improve small-farm productivity; and linking small-farm families to markets their farm produce. A couple of PRISM projects are being implemented by IDE Nepal both in hills and terai district of Nepal. Kaski district in the hill and Kapilvastu district in the Terai were randomly selected for the study under IDE PRISM project. The output traders buy the vegetable products and market them at local, regional, national and international levels (Nepal and Thapa, 2009). All the stakeholders are key actors and they play the vital role in the growth and development of the vegetable subsectors. The main idea of this study was to assess the impact of vegetable sub-sector before and after the vegetable program through PRISM approach in the above mentioned districts especially in the area of area under vegetable cultivation, production of vegetables, sale of vegetables and income of the vegetable growers.

\section{MATERIALS AND METHODS}

For this study, in Kaski district, 15 farmers' groups with 105 numbers of household head (7 from each group) and 24 groups with 168 household head in Kapilvastu were randomly selected for interview. Random table number was used for the selection of districts, groups and household heads. Sample households were interviewed with pre-tested questionnaires. Information on inputs and technology availability, irrigation management, crop husbandry and post harvest market accessibility was collected as per the questionnaires. The data were analyzed using SPSS Statistical Software Package. The descriptive statistical tools, such as means, mode, frequencies and percentage and inferential statistics such as t-Test and regression analysis were used for data analyses. Conditions or situations on different aspects of the vegetable farming through PRISM approach pre- and post-project periods were compared. As PRISM projects were in operation since a decade, comparisons of before ten years and after were made. The information collected was based on memory power of the respondents. Transformations/positive changes brought about by the PRISM project were noted and inferences were drawn based on these comparisons.

\section{RESULTS AND DISCUSSION}

\section{Area under vegetable cultivation}

Area under vegetable cultivation is one of the important aspects of the commercial farming. When the small areas of several farmers were combined and farmed the area is big enough to invite the necessary inputs for the technology adaptation. The mean area of vegetable cultivation highly significantly increased after the project in Kaski and Kapilvastu as compared to before the project intervention (Table 1). Vegetables grown also highly significantly differed in Kaski but were nonsignificant in Kapilvastu. The traders were attracted to high volume of the produce available in pocket area. The PRISM project supported farmers with the package of program, in which all the possibilities of input, credits and marketing system was included. It shows that vegetable was cultivated in both the study areas even before the PRISM project; then the area was 387 ropani, which expanded to 1889 ropani after the project in Kaski. Similarly, the farmers cultivating 939 ropani increased to 2880 ropani in Kapilvastu after the implementation of project. About the season of growing 221 Ropani of area was covered by winter vegetables in Kaski and 166 Ropani of summer vegetables, whereas 1326 Ropani area was under winter vegetables and 1555 Ropani under summer vegetables in Kapilvastu (Table 1).

Table 1: Total areas under vegetables farming by respondents in Kaski and Kapilvastu districts

\begin{tabular}{|c|c|c|c|c|c|c|}
\hline \multirow{2}{*}{ Particulars } & \multicolumn{2}{|c|}{ Kaski } & \multicolumn{2}{|c|}{ Kapilvastu } & \multicolumn{2}{|c|}{ Total } \\
\hline & Before & After & Before & After & Before & After \\
\hline \multirow[t]{2}{*}{ Area (Ropani) $^{1}$} & 387 & 1889 & 939 & 2880 & 1326 & 4769 \\
\hline & \multicolumn{2}{|c|}{ t-test ${ }^{\star *}$} & \multicolumn{2}{|c|}{ t-test ${ }^{* *}$} & \multicolumn{2}{|c|}{ t-test ${ }^{\star *}$} \\
\hline \multirow[t]{2}{*}{ Vegetable grown in winter (Ropani) ${ }^{1}$} & 221 & 1077 & 563 & 1325 & 796 & 2241 \\
\hline & \multicolumn{2}{|c|}{ t-test ${ }^{\star *}$} & \multicolumn{2}{|c|}{ t-testns } & \multicolumn{2}{|c|}{ t-testns } \\
\hline \multirow[t]{2}{*}{ Vegetable grown in summer (Ropani) ${ }^{1}$} & 166 & 812 & 376 & 1555 & 530 & 2527 \\
\hline & \multicolumn{2}{|c|}{$t$-test ${ }^{* *}$} & \multicolumn{2}{|c|}{ t-testns } & \multicolumn{2}{|c|}{ t-test ${ }^{*}$} \\
\hline
\end{tabular}

${ }^{1}(20$ ropani $=1 \mathrm{ha}) ;{ }^{*} \mathrm{t}$-critical value $(0.05$ level $)$ and ${ }^{* *}(0.01$ level $)$ before and after the project in each row indicate significance difference in comparing their means, and ns indicates non-significant. 1 Ropani $=500$ Square meter. 


\section{Annual income of the respondents}

Farmers cultivated their farms for the sake of income and food security. Here in these study districts farms income was less than the other non-farm income. When comparing the two districts, Kaski district had more farm income than the Kapalvastu district. The margin was wide before implementation of the PRISM project. However, after the project, the income of Kapilvastu farmers also increased, but was less than the Kaski district.

The study revealed that the PRISM project had highly significant impact on the income of the farmers while comparing before and after the project intervention (Table 2). In Kaski, the farmers almost doubled their income, i.e. from NRs. 33467 before the project to NRs. 60846 after the project. The farmers in Kapilvastu received $>10$ times increase in their farm income (NRs. 41259) after the project. After the project non-farm income also significantly increased (Table 2).

Table 2: Total annual income of the respondents in Kaski and Kapilvastu districts

\begin{tabular}{|c|c|c|c|c|c|c|}
\hline \multirow{2}{*}{ Income of respondents } & \multicolumn{2}{|c|}{ Kaski } & \multicolumn{2}{|c|}{ Kapilvastu } & \multicolumn{2}{|c|}{ Total } \\
\hline & Before & After & Before & After & Before & After \\
\hline \multirow[t]{2}{*}{ Total farm income (NRs/HH) } & 33467 & 60846 & 4121 & 41259 & 23544 & 48804 \\
\hline & \multicolumn{2}{|c|}{ t-test $^{\star *}$} & \multicolumn{2}{|c|}{ t-test ${ }^{\star *}$} & \multicolumn{2}{|c|}{ t-test $^{\star *}$} \\
\hline \multirow[t]{2}{*}{ Total non-farming income $(\mathrm{NRs} / \mathrm{HH})$} & 75455 & 234289 & 4737 & 98698 & 57442 & 149392 \\
\hline & \multicolumn{2}{|c|}{ t-test $^{\star *}$} & \multicolumn{2}{|c|}{ t-test ${ }^{\star \star}$} & \multicolumn{2}{|c|}{ t-test $^{\star *}$} \\
\hline \multirow[t]{2}{*}{ Total annual income (NRs/HH) } & 91285 & 248303 & 7076 & 162501 & 61249 & 196688 \\
\hline & \multicolumn{2}{|c|}{ t-test $^{* *}$} & \multicolumn{2}{|c|}{ t-test $^{\star *}$} & \multicolumn{2}{|c|}{ t-test $^{* *}$} \\
\hline
\end{tabular}

* t- critical value $\left(0.05\right.$ level) and ${ }^{* *}(0.01$ level $)$ before and after the project in each row indicate significance difference in comparing their means. (1 US Dollar $=76.12$ Nepali Rupees at base year, 2003 and 90.35 Nepali Rupees by the end of the project, 2012)

For the poor in developing countries, their growth is dependent on agricultural productivity, which provides sufficient food for a growing non-agricultural population. Improved technology increases agricultural productivity that drives a rural growth process of inherently pro-poor (Andy et al., 1991; Page et al., 2009).

\section{Vegetable farming area and use of labor}

The study showed that the vegetable farming area and labor use highly significantly increased after the project in both, Kaski and Kapilvastu districts as compared to before the project intervention. Similarly, male female farm working and hired labor including their wages were found significant increased after the project (Table 3). The survey result shows that the average area under vegetable farming for both Kaski and Kapilvastu was 0.1 ha which is 3 times higher than project base year, i.e. before ten years. The average area under vegetable cultivation in Kaski and Kapilvastu was 0.07 and 0.11 ha after the project intervention, respectively indicating more area under vegetable cultivation in Kapilvastu. Male and female member working in vegetable farm also increased after ten years showing the positive direction towards commercial vegetable farming. The number of hired female labor and the wage rate (both male and female labor) was higher in Kaski than in Kapilvastu. However, higher wage rate was fixed to male labors by $47 \%$ and $42 \%$ even before and after the PRISM project in Kaski, respectively. Similarly, $31 \%$ and $16 \%$ higher wages was received by male labor in Kapilvastu before and after the PRISM project, respectively (Table 3). 
Table 3: Vegetable farming area, labor use and wage rate in Kaski and Kapilvastu districts

\begin{tabular}{|c|c|c|c|c|c|c|}
\hline \multirow[t]{2}{*}{ Particulars } & \multicolumn{2}{|l|}{ Kaski } & \multicolumn{2}{|c|}{ Kapilvastu } & \multicolumn{2}{|c|}{ Both } \\
\hline & Before & After & Before & After & Before & After \\
\hline \multirow[t]{2}{*}{ Land under vegetable farming (Ropani) ${ }^{1}$} & 0.6 & 1.4 & 1.9 & 2.3 & 0.7 & 1.9 \\
\hline & \multicolumn{2}{|c|}{ t-test ${ }^{\star *}$} & \multicolumn{2}{|c|}{ t-test ${ }^{\star \star}$} & \multicolumn{2}{|c|}{ t-test ${ }^{\star \star}$} \\
\hline \multirow[t]{2}{*}{ Person working in vegetable farm (No) } & 2 & 3 & 2 & 3 & 2 & 3 \\
\hline & \multicolumn{2}{|c|}{ t-test ${ }^{\star *}$} & \multicolumn{2}{|c|}{ t-test ${ }^{\star \star}$} & \multicolumn{2}{|c|}{ t-test ${ }^{\star *}$} \\
\hline \multirow[t]{2}{*}{ Male member working in farm (No) } & 1 & 1.2 & 1.6 & 1.7 & 1 & 1.5 \\
\hline & \multicolumn{2}{|c|}{ t-test ${ }^{*}$} & \multicolumn{2}{|c|}{ t-test ${ }^{* *}$} & \multicolumn{2}{|c|}{ t-test ${ }^{\star *}$} \\
\hline \multirow[t]{2}{*}{ Female member working in farm (No) } & 1 & 1.3 & 1.3 & 1.8 & 1.2 & 1.6 \\
\hline & \multicolumn{2}{|c|}{ t-test ${ }^{\star *}$} & \multicolumn{2}{|c|}{ t-test ${ }^{* *}$} & \multicolumn{2}{|c|}{ t-test ${ }^{* *}$} \\
\hline \multirow[t]{2}{*}{ Hired male labor working in farm (No) } & 1 & 1.3 & 1.3 & 2.3 & 1.2 & 1.8 \\
\hline & \multicolumn{2}{|c|}{ t-test ${ }^{* *}$} & \multicolumn{2}{|c|}{ t-test ${ }^{* *}$} & \multicolumn{2}{|c|}{ t-test ${ }^{\star *}$} \\
\hline \multirow[t]{2}{*}{ Hired female labor working in farm (No) } & 26 & 21 & 1.5 & 1.7 & 9 & 12 \\
\hline & \multicolumn{2}{|c|}{ t-test ${ }^{*}$} & \multicolumn{2}{|c|}{ t-test ${ }^{* *}$} & \multicolumn{2}{|c|}{ t-test ${ }^{\star *}$} \\
\hline \multirow[t]{2}{*}{ Wage of male labor (NRs/day) } & 198 & 394 & 96 & 208 & 128 & 264 \\
\hline & \multicolumn{2}{|c|}{ t-test ${ }^{\star *}$} & \multicolumn{2}{|c|}{ t-test ${ }^{\star *}$} & \multicolumn{2}{|c|}{ t-test ${ }^{\star *}$} \\
\hline \multirow[t]{2}{*}{ Wage of female labor (NRs/day) } & 105 & 227 & 66 & 175 & 78 & 190 \\
\hline & \multicolumn{2}{|c|}{ t-test** } & \multicolumn{2}{|c|}{ t-test* } & \multicolumn{2}{|c|}{ t-test ${ }^{\star *}$} \\
\hline
\end{tabular}

1. (20 ropani $=1 \mathrm{ha}) ;{ }^{*}$ t-critical value $(0.05$ level $)$ and ${ }^{* *}(0.01$ level $)$ before and after the project in each row indicate significance difference in comparing their means. (1 US Dollar $=76.12$ Nepali Rupees at base year, 2003 and 90.35 Nepali Rupees by the end of the project, 2012)

\section{Vegetable production, consumption and net return}

Total production, consumption and net-return received by the respondents from vegetable growing in Kaski and Kapilvastu districts are presented in Table 4. There was highly significant increase in production, consumption, and sale, gross and net income of vegetables farming in surveyed area over the period of ten years. The findings revealed that there was about 6 times increase in Kaski and 12 times in Kapilvastu. The productivity of vegetables increased from $24 \mathrm{mt}$ to $28.8 \mathrm{mt}$ in Kaski and $4.2 \mathrm{mt}$ to $17.8 \mathrm{mt}$ in Kapilvastu over the project period of ten years. Both together, increase in productivity was 10.28 to $22.2 \mathrm{mt}$ per ha over the project period. 
Table 4: Total production, consumption and net-return received by the respondents from vegetable growing in Kaski and Kapilvastu districts

\begin{tabular}{|c|c|c|c|c|c|c|}
\hline \multirow{2}{*}{ Particulars } & \multicolumn{2}{|c|}{ Kaski } & \multicolumn{2}{|c|}{ Kapilvastu } & \multicolumn{2}{|c|}{ Both } \\
\hline & Before & After & Before & After & Before & After \\
\hline Vegetable production per group (mt) & \multicolumn{2}{|c|}{ t-test ${ }^{* *}$} & \multicolumn{2}{|c|}{ t-test ${ }^{\star \star}$} & \multicolumn{2}{|c|}{ t-test ${ }^{\star \star}$} \\
\hline \multirow[t]{2}{*}{ Vegetable production (kg/ropani) } & 1243 & 1443 & 213 & 892 & 514 & 1110.4 \\
\hline & \multicolumn{2}{|c|}{ t-test ${ }^{\star \star}$} & \multicolumn{2}{|c|}{ t-test** } & \multicolumn{2}{|c|}{ t-test ${ }^{\star *}$} \\
\hline Vegetable production (mt/ha) & $\begin{array}{l}24 \\
\text { t-test }\end{array}$ & 28.8 & $\begin{array}{l}4.2 \\
\text { t-tes }\end{array}$ & 17.8 & $\begin{array}{l}10.28 \\
\text { t-test }\end{array}$ & 22.2 \\
\hline Home consumption (mt) & $\begin{array}{l}250 \\
\text { t-test }\end{array}$ & 635 & $\begin{array}{l}64 \\
\text { t-tes }\end{array}$ & 565 & $\begin{array}{l}327.2 \\
\text { t-test }\end{array}$ & * 1165 \\
\hline Sell in the market (mt) & \multicolumn{2}{|c|}{ t-test $^{\star *}$} & \multicolumn{2}{|c|}{ t-test ${ }^{* *}$} & $\begin{array}{l}354.5 \\
\text { t-test }\end{array}$ & * 4130.5 \\
\hline Gross income minimum (NRs) & \multicolumn{2}{|c|}{ t-test ${ }^{\star *}$} & \multicolumn{2}{|c|}{ t-test ${ }^{\star *}$} & \multicolumn{2}{|c|}{ t-test ${ }^{* *}$} \\
\hline Gross income maximum (NRs) & \multicolumn{2}{|c|}{$\begin{array}{l}1520 \\
\text { t-test }\end{array}$} & \multicolumn{2}{|c|}{ t-test ${ }^{* *}$} & \multicolumn{2}{|c|}{ t-test ${ }^{\star *}$} \\
\hline Net income (NRs/hh) & $\begin{array}{r}1166.69 \\
\text { t-test }\end{array}$ & 25240.6 & $\begin{array}{r}4451.75 \\
\text { t-tes }\end{array}$ & 20425.4 & $\begin{array}{c}1635.98 \\
\text { t-test }^{*}\end{array}$ & 22451.8 \\
\hline
\end{tabular}

${ }^{*}$ t-critical value $(0.05$ level $)$ and ${ }^{* *}(0.01$ level $)$ before and after the project in each row indicate significance difference in comparing their means. 1 Ropani $=500$ Square meter. .( 1 US Dollar $=76.12$ Nepali Rupees at base year, 2003 and 90.35 Nepali Rupees by the end of the project, 2012)

Before ten years, on an average, about $48 \%$ of vegetable produced was consumed while only $22 \%$ of vegetable produced was consumed after ten years indicating that about $78 \%$ of vegetable produced was sold at the market. The consumption of vegetables was higher in Kaski as compared to Kapilvastu. Over the period of ten years time, the net income increased per household from the sale of vegetable was NRs.1166. to NRs.25240. and from NRs. 4451 to NRs. 20425. in Kaski and Kapilvastu, respectively. On an average, the net increase in household income of the surveyed area from the sale of vegetable was NRs. 1635.to NRs.22451 (Table 4).

Regression analysis was performed on the vegetable production as contributing results of winter plus summer vegetables farming and labor utilization, thereby diversifying different kinds of vegetables during winter and summer seasons, with labor employment opportunity (both farm and hired labors) during vegetable growing and sale of the produce in the market through cooperative management. The multiple regressed F-values pooled of both district are shown in table 5 and 6 . It was highly significant $(p<0.01)$. This explained nearly $2 / 3^{\text {rd }}$ of the vegetable production contributed by the seasonal vegetable growing and farm plus hired labors $\left(R^{2}=64.55\right)$ working on the farm.

To enter the market and trade with commercial entities, farmers needed to become a legal entity, and consequently they have to organize themselves into associations. This is one way of facilitating the creation of farmers' association, organized marketing committees and equipped farmers to conduct market research and develop market linkages (Shepherd, 2007).

The farmers were organized in a group of 15 to 20 members and registered in the District Agricultural Development Office. They had their own contact person who collected and communicated the information to other members of the groups. This types of organization is found in many countries (Farmer et al., 2011). These groups collect their products in the collection centers and the traders come and negotiate product price themselves. The groups also have the information collected from the consumers prices from the vegetable marketing centers at the grass root levels (Mottaleb et al., 2015; Pastakia, 1998).

\section{SUMMARY AND CONCLUSIONS}

Different projects with PRISM approach have been implemented since 1998 to 2008 both in Hills and Terai of Nepal. This study examines the impact of PRISM approach in selected districts- Kaski and Kapilvastu in relation to increase in area under vegetable cultivation, increase in production and productivity of vegetables and increase in income of

the vegetable growers after the PRISM project. It has contributed to poverty alleviation by linking small farm families to market their farm produce for effective and sustainable income.

The project mainly intervened in networking of agricultural supplies to facilitate the small farmers and increase production and productivity. After the 
production increased marketing channel was developed, where producers and traders had direct contact and linkages for the marketing of their vegetable produce. This project provided the development and the facilitation of all the actors involved in input supply, production and marketing of the farm produce. The improvement made by the PRISM project in the area of input supply, production and marketing of the farm produce has impacted on Increase in area under vegetable farming, increase in production and productivity of vegetables and increase in income of the vegetable farmers of the studied districts.

\section{REFERENCES}

Andy, J., H. Eric and O.D. Mike. 1991. Technology : The key to increasing the productivity of microenterprises. Small Enterprise Development 2:14-23.

Bryant, L. 1999. The detraditionalization of occupational identities in farming in South Australia. Sociologia Ruralis 39:236-261.

Farmer, S.M., X. Yao and K. Kung-Mcintyre. 2011. The behavioral impact of entrepreneur identity aspiration and prior entrepreneurial experience. Entrepreneurship Theory and Practice 35:245-273.

Mottaleb, K.A., S. Mohanty and A. Nelson. 2015. Strengthening market linkages of farm households in developing countries. Applied Economic Perspectives and Policy 37:226-242.

Nepal, R. and G.B. Thapa. 2009. Determinants of agricultural commercialization and mechanization in the hinterland of a city in Nepal. Applied Geography 29:377-389.

Page, S.J., M. Baksh, E. Duveiller and S. Waddington. 2009. Putting the poorest farmers in control of disseminating improved wheat seed: A strategy to accelerate technology adoption and alleviate poverty in Bangladesh. Food Security 1:99-109.

Pastakia, A. 1998. Grassroots ecopreneurs: Change agents for a sustainable society Journal of Organizational Change Management 11:157 - 173.

Shepherd, A.W. 2007. Experiences with the "Linking Farmers To Markets" approach in enhancing the performance of horticultural supply chains in the transitional economies ISHS Acta Horticulturae 794: II International Symposium on Improving the Performance of Supply Chains in the Transitional Economies 